RFP-4339

January 16,1991
RFP- -4339

DE92 007357

FEB $0310 \%$

\title{
MAGNESIUM OXIDE INSERTS FOR THE LECO CARBON ANALYZER
}

\author{
L. M. Bagaasen \\ C. M. Jensen
}

\section{DISCLAIMER}

This report was prepared as an account of work sponsored by an agency of the United States Government. Neither the United States Government nor any agency thereof, nor any of their employees, makes any warranty, express or implied, or assumes any legal liability or responsibility for the accuracy, completeness, or usefulness of any information, apparatus, product, or process disclosed, or represents that its use would not infringe privately owned rights. Reference herein to any specific commercial product, process, or service by trade name, trademark, manufacturer, or otherwise does not necessarily constitute or imply its endorsement, recommendation, or favoring by the United States Government or any agency thereof. The views and opinions of authors expressed herein do not necessarily state or reflect those of the United States Government or any agency thereof.

\section{@ EGLE ROCKY FLATS \\ Rocky Flats Plant \\ P. O. Box 464 \\ Golden, Colorado 80402-0464}

\section{U.S. DEPARTMENT OF ENERGY CONTRACT DE-ACO4-90DE62349}




\section{DISCLAIMER}

This report was prepared as an account of work sponsored by an agency of the United States Government. Neither the United States Government nor any agency thereof, nor any of their employees, makes any warranty, expressed or implied, or assumes any legal liability or responsibility for the accuracy, completeness, or usefulness of any information, apparatus, product, or process disclosed, or represents that its use would not infringe privately owned rights. Reference herein to any specific commercial product, process, or service by trade name, trademark, manufacturer, or otherwise, does not necessarily constitute or imply its endorsement, recommendation, or favoring by the United States Government or any agency thereof. The view and opinions of authors expressed herein do not necessarily state or reflect those of the United States Government or any agency thereof.

This report has been reproduced directly from the best available copy.

Available to DOE and DOE contractors from the Office of Scientific and Technical Information, P. O. Box 62, Oak Ridge, TN 37831; prices available from (615) 576-8401, FTS 626-8401.

Available to the public from the National Technical Information Service, U.S. Department of Commerce, 5285 Port Royal Rd., Springtield, VA 22161. 


\title{
MAGNESIUM OXIDE INSERTS FOR THE LECO CARBON ANALYZER
}

L. M. Bagaasen

C. M. Jensen

\section{SUBJECT DESCRIPTORS}

Dissolution LECO Carbon Analysis LECO Crucibies

Magnesium Oxide Inserts

Nitric Acid/Calcium

Fluoride

Plutonium Recovery

EG\&G ACCKY FLATS, INC.

ROCKY FLATS PLANT

P. O. BOX 464

GOLDEN, COLORADO 80402-0464

\author{
PREPARED UNDEA CONITACT DE-ACO4-9ODES2349 \\ FOR THE \\ ALQUQUEAQUE OPEAATONS OFFICE \\ U.S. DEPARTMENT OF ENEFGY
}


RFP-4339 


\section{CONTENTS}

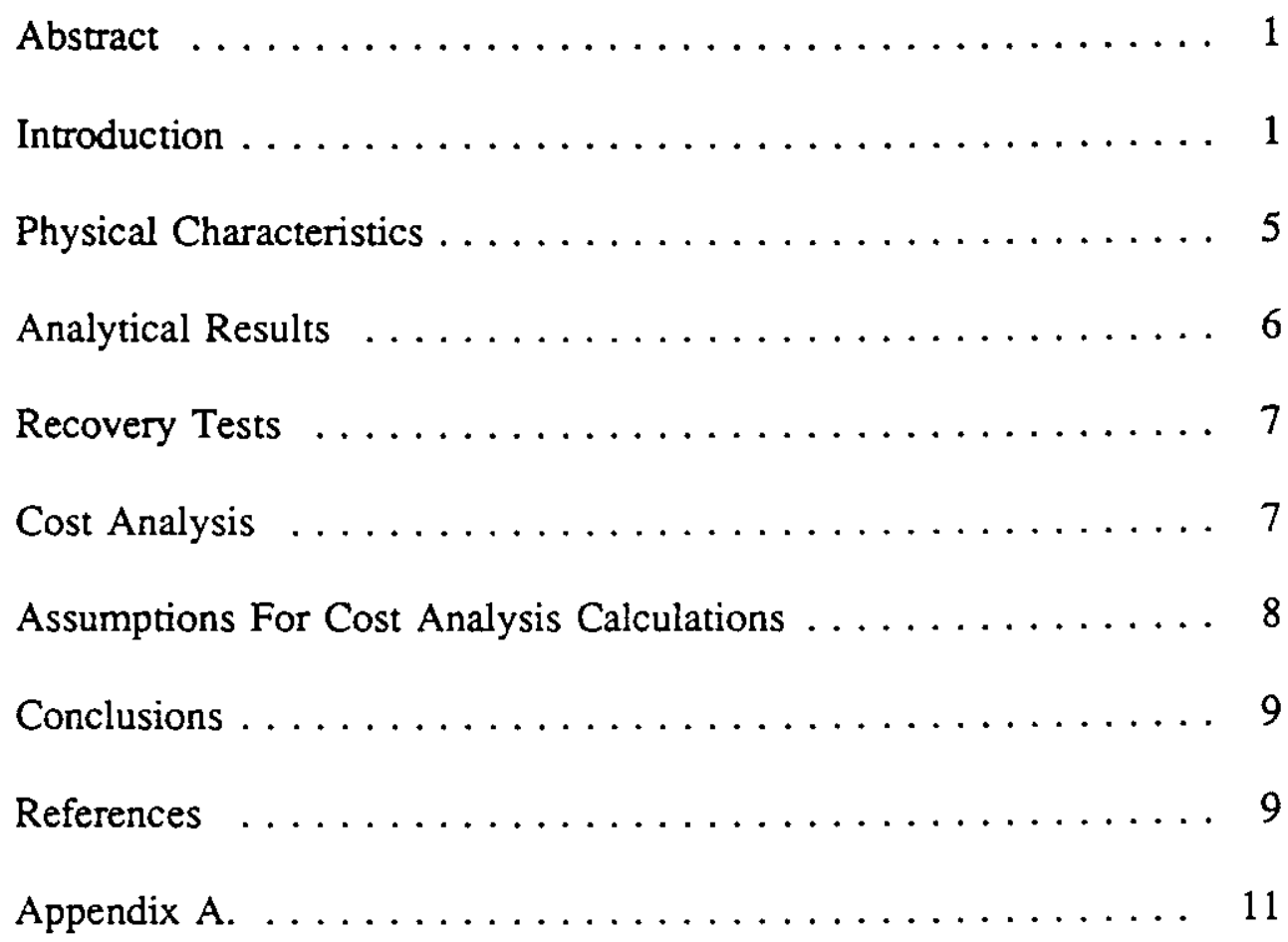


RFP-4339 


\title{
MAGNESIUM OXIDE INSERTS FOR THE LECO CARBON ANALYZER
}

\author{
L. M. Bagaasen and C. M. Jensen
}

\begin{abstract}
LECO carbon analysis of plutonium metal and plutonium oxide at the Rocky Flats Plant generates several hundred kilograms of high silica residues each year. The plutonium in these residues is difficult and expensive to recover using production dissolution processes. A magnesium oxide (MgO) insert has been developed that significantly lowers the plutonium recovery costs without adversely affecting accuracy of the carbon analysis.
\end{abstract}

After investigating several different microstructures and shapes, the best insert for the LECO carbon analyzer was found to have a low-density ( 2.7 $\mathrm{g} / \mathrm{cm}^{3}$ ), high-fired microstructure and a shape that included thin walls $(0.140 \mathrm{inch})$ and a thick bottom ( 0.400 inch). Initial investigations also determined that although inserts naturally adsorb detrimental carbon dioxide during room temperature storage, the carbon dioxide is readily removed prior to analysis by refiring the crucibles at $1000^{\circ} \mathrm{C}$ for 30 minutes.

Chemical analysis of LECO crucibles used as holders for 25 analyses indicated that $99.9 \%$ of the plutonium remained in the $\mathrm{MgO}$ inserts. In a trial recovery test using 370 inserts, more than $98 \%$ of the plutonium in the inserts was recovered in a single pass through a production nitric acid/calcium fluoride dissolution line. It has been estimated that the yearly cost of recovering plutonium from the $\mathrm{MgO}$ inserts will be $\$ 108,000$ to $\$ 251,000$ less than the anticipated cost of LECO crucibles without inserts.

\section{INTRODUCTION}

The carbon content of plutonium metal and oxide are routinely analyzed with a LECO Carbon Analyzer@. This analyzer (Figure 1) uses a

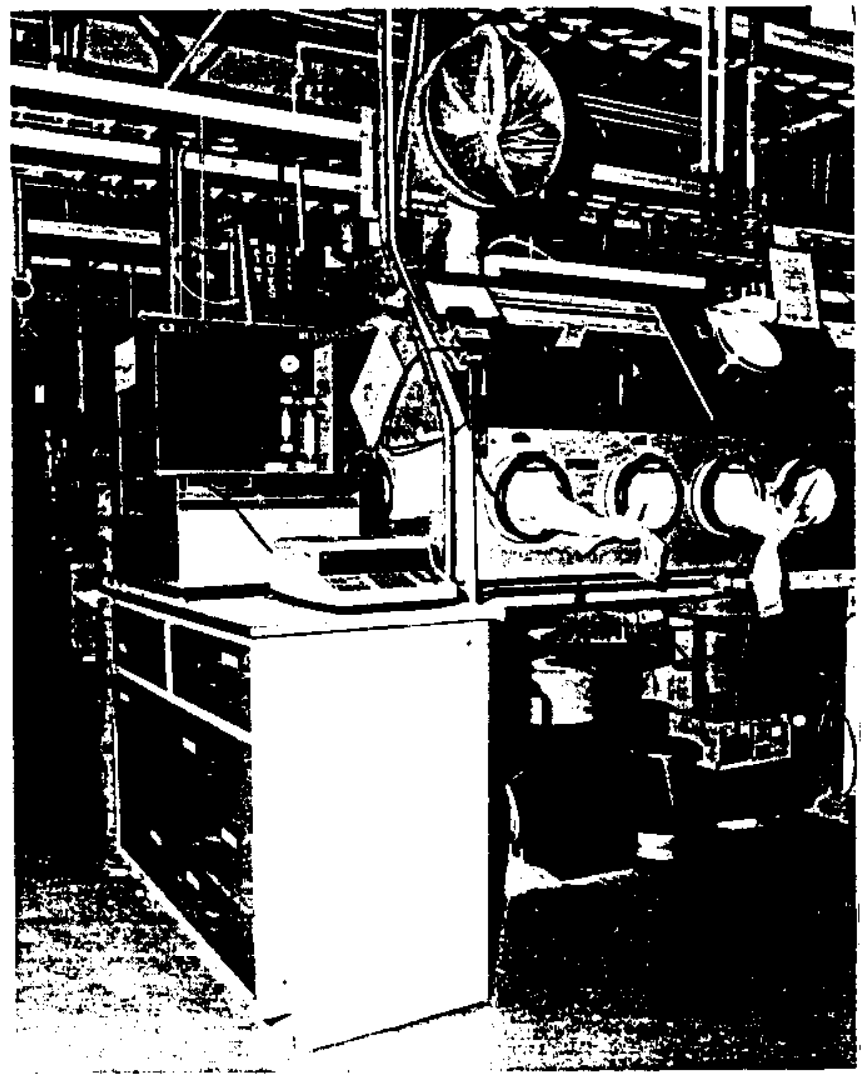

FIGURE 1. LECO Carbon Analyzer Used for Determining the Carbon Content of Plutonium Metal and Plutonium Oxide Samples

combustion-infrared detection technique to determine carbon content of samples. For carbon analysis of plutonium, a sample of known weight (approximately $0.5 \mathrm{~g}$ ) is placed in a ceramic crucible containing one $\mathbf{g}$ of copper metal accelerator. The crucible is loaded into the LECO's induction furnace, and the sample is heated while being purged with oxygen. The conductive copper acts as an accelerator and helps fully oxidize the plutonium and release all the 


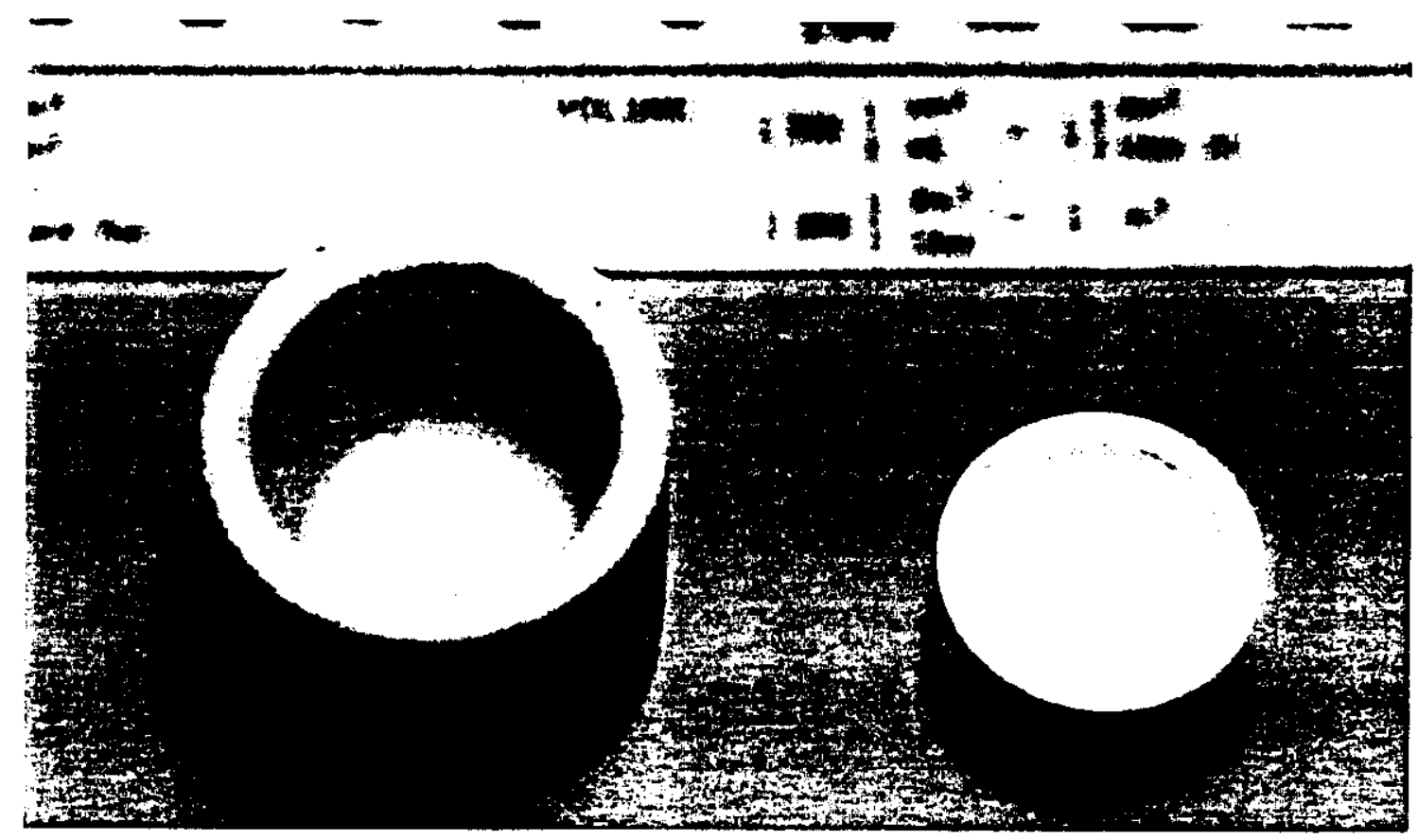

FIGURE 2. LECO Crucible and Magnesium Oxide Insert. The LECO crucible (left) contains $>90 \%$ silica, and the remainder is mainly alumina and chromic oxide. The magnesium oxide insert (right) contains $>98 \%$ magnesium oxide.

carbon. The combustion gases containing the released carbon are passed through an infrared detector, and the total carbon content of the sample is determined. During analysis, the copper and plutonium combine to form a melt, which penetrates into the walls of the LECO crucible.

For the past 10-15 years, carbon analysis has been performed using a conventional LECO crucible composed of $>90 \%$ silica with the remainder consisting mainly of chromic oxide and alumina. This composition resists thermal shock and effectively contains molten materials during analysis but is difficult to crush, dissolve, and recover. Consequently, a large backlog of residue accumulated. This residue contains a significant amount of unused plutonium and has created storage problems. ${ }^{1}$

The purpose of this study was to determine whether $\mathrm{MgO}$ inserts can simplify recovery of the plutonium in the LECO carbon analysis process. These inserts would be used as illustrated in
Figures 2 through 6 . First, the $\mathrm{MgO}$ insert is placed in a standard LECO crucible and loaded with copper accelerator and the plutonium sample (Figures 2 through 4). Next, the sample is placed into the induction furnace and burned at high temperatures in an oxygen atmosphere. As in the normal operation of the LECO carbon analyzer, the carbon is released and analyzed during this hightemperature combustion. However, in this case, the plutonium does not penetrate into the walls of the LECO crucible, but instead is contained in the recoverable $\mathrm{MgO}$ insert (Figure 5).

After cooling, the insert can be separated from the LECO crucible by inverting and tapping (Figure 6). Then, the MgO insert with the copper and plutonium oxide residues is recovered using a nitric acid/calcium fluoride dissolution process, while the LECO crucible holder is reused.

To thoroughly investigate feasibility of using these inserts, the study was divided into four areas. First, physical characteristics of an $\mathrm{MgO}$ insert to 


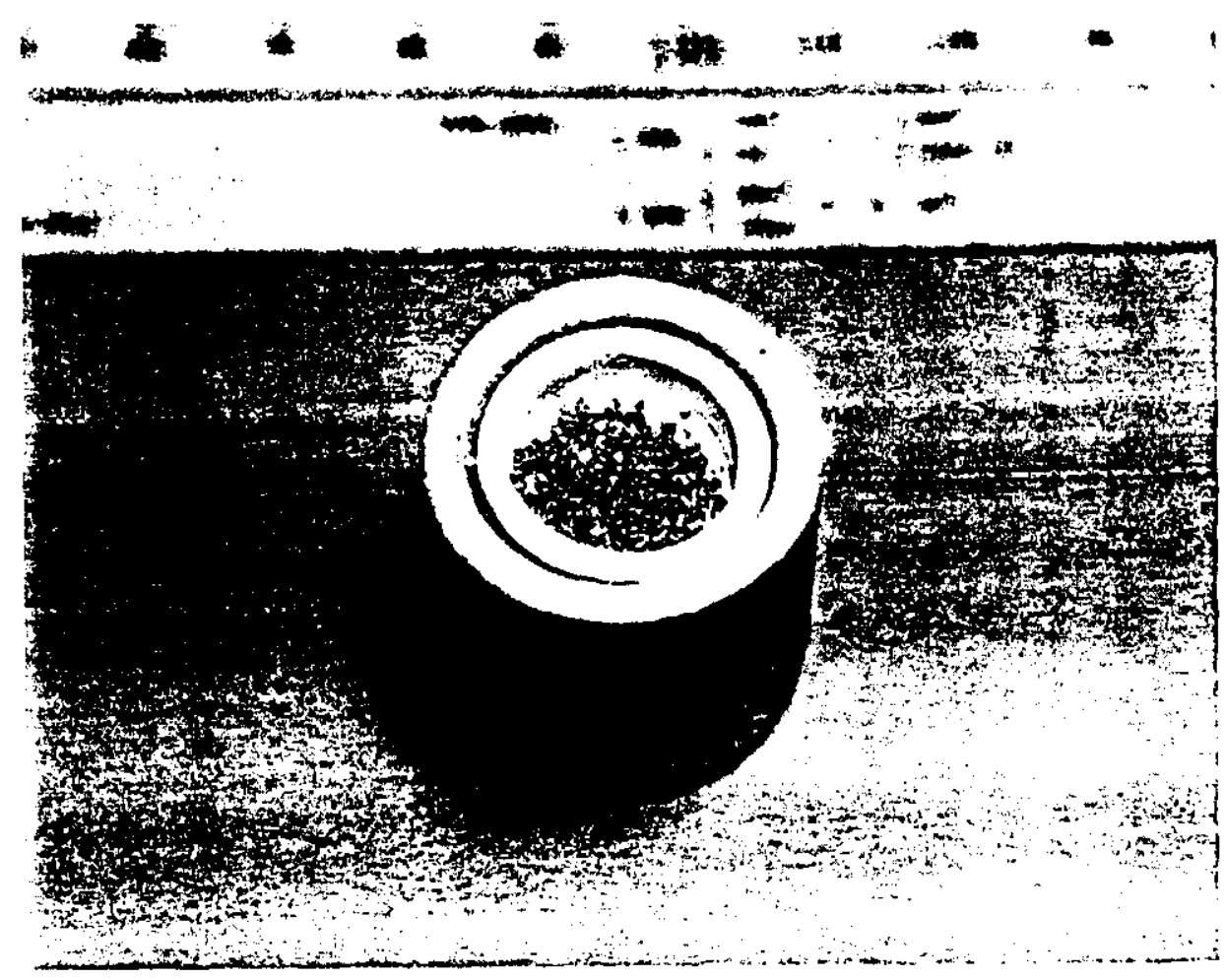

FIGURE 3. Magnesium Oxide Inscrt Loaded with Copper Accelerator and Placed in LECO Crucible. The copper accelerator readily melts and helps to fully oxidize the plutonium sample.

FIGURE 4. Magnesium Oxide Insert Loaded with Copper Accelerator and Plutonium Metal Sample and Placed in LECO Crucible. The crucible at this point is ready for carbon analysis.

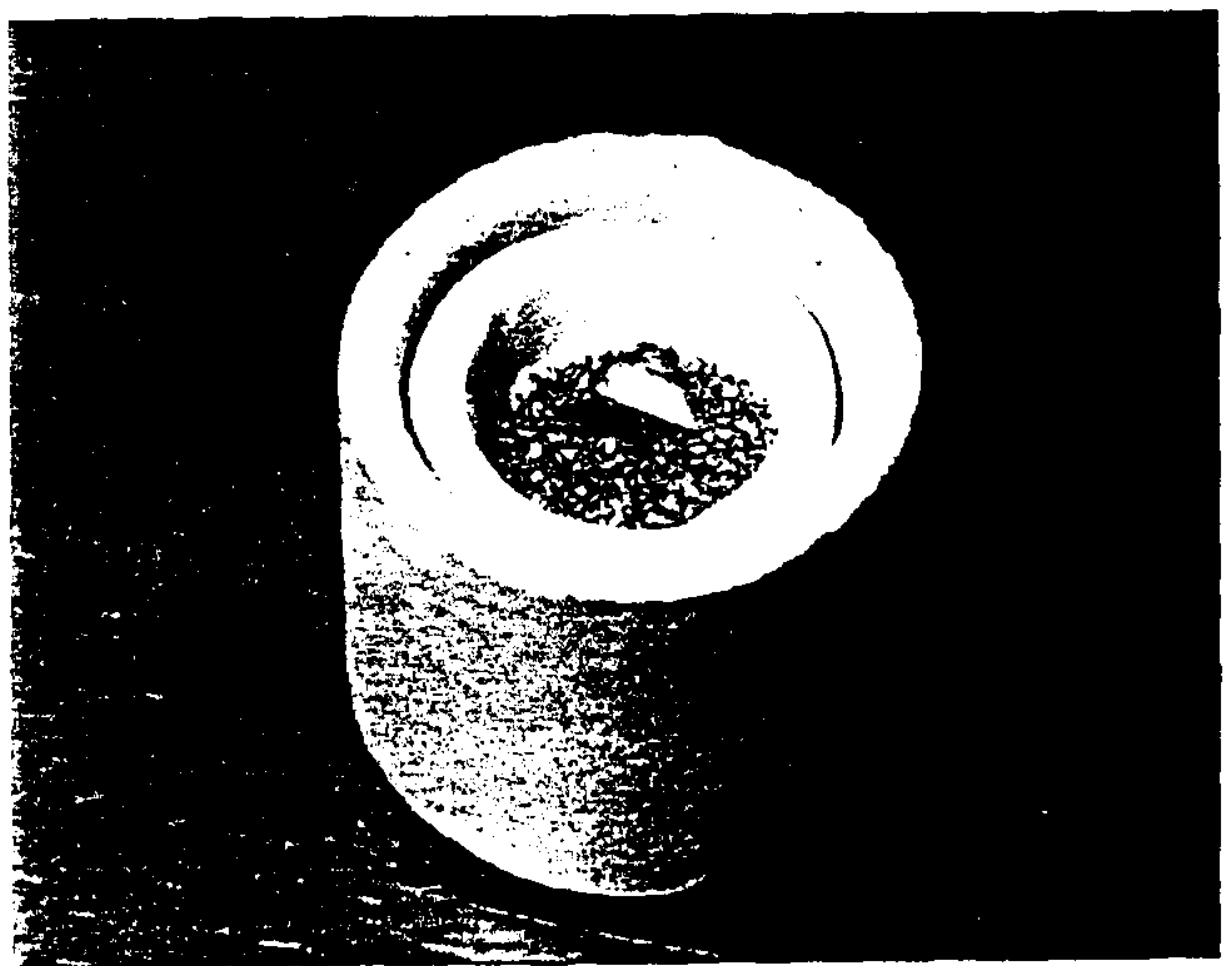




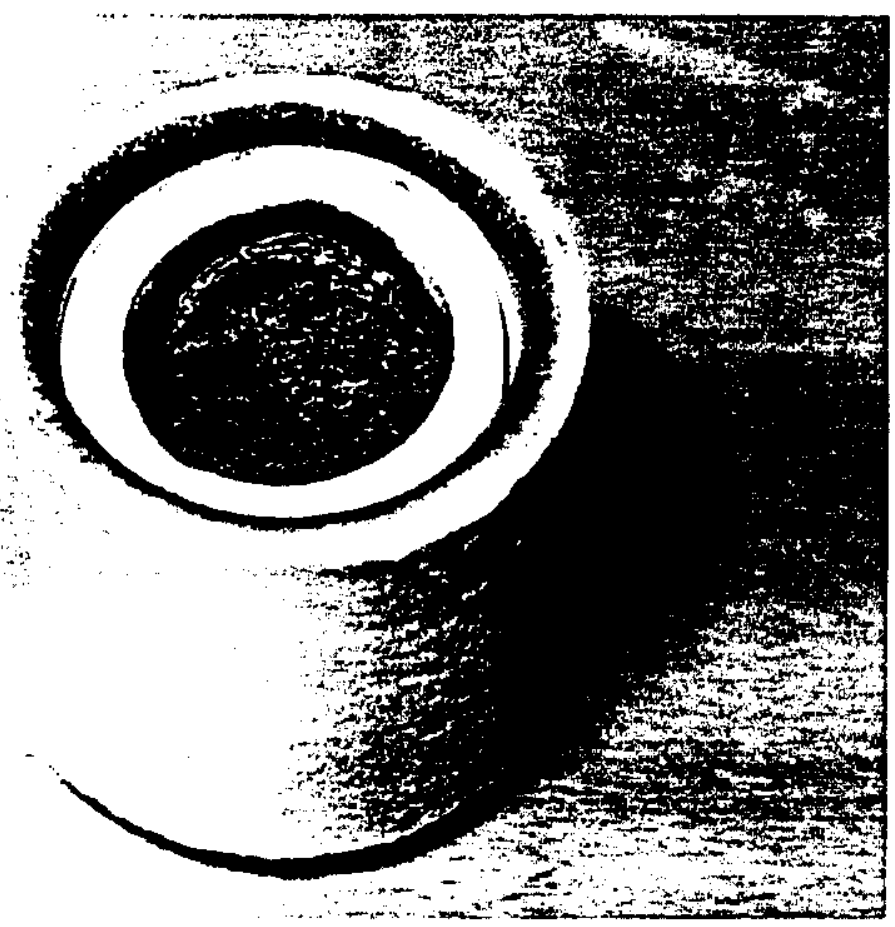

FIGURE 5. Magnesium Oxide Insert and LECO Crucible After Carbon Analysis. Immediately after analysis, the insert is physically wedged into the LECO crucible because of differential thermal expansion.

FIGURE 6. Magnesium Oxide Insert Removed from the LECO Crucible. After 30-60 seconds of cooling, the insert can readily be removed from the LECO crucible. Darkening of the insert and inner wall of the LECO crucible results from molten copper metal penetrating through the walls of the insert. Most of the plutonium remains in the insert. At this point, the insert can be recovered, and the LECO crucible can be reused as a holder.

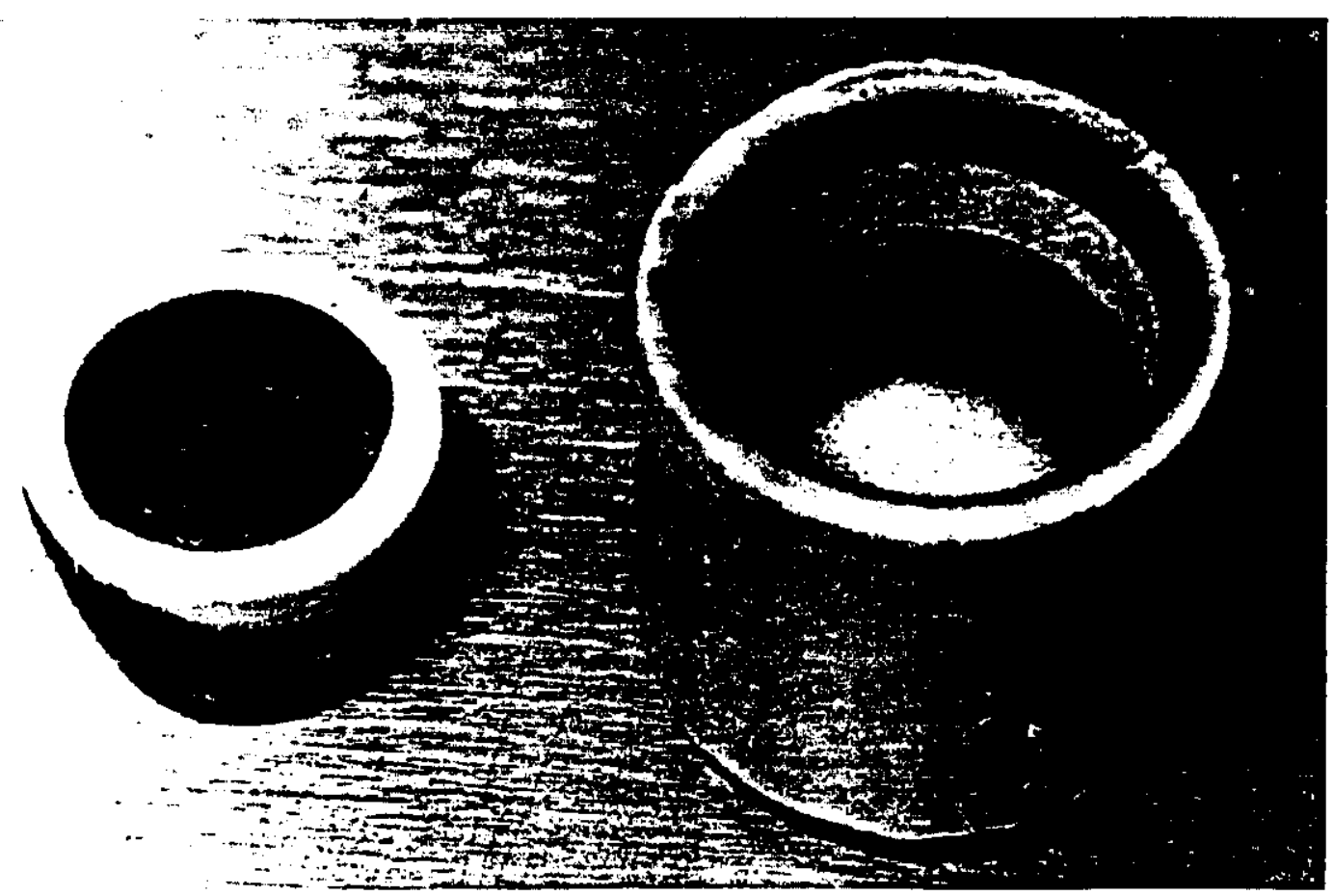


contain the plutonium metal during the LECO Carbon Analysis were determined. Second, effects of the $\mathrm{MgO}$ inserts on analytical results were examined. Third, the ability to recover plutonium from the MgO inserts was verified. And fourth, an analysis was conducted to determine the cost of using the inserts.

\section{PHYSICAL CHARACTERISTICS}

Initially, it was necessary to determine the proper geometry and microstructure of the insert. Several different crucibles were tested to determine which shape worked best in the LECO carbon analyzer. Crucibles with thick walls and bottoms contained the plutonium but did not allow the copper accelerator to fully melt and help oxidize the plutonium sample. This was probably caused by the combined insulating effect of the $\mathrm{MgO}$ inser and the LECO ceramic crucible holder. When crucibles with thin walls and bottoms were used, the copper fully melted but bumed through the bottom of the insert, causing the insert to stick to the holder. Thus, the best design was a crucible with relatively thin walls $(0.140$ in.) and a thick bottom (0.400 in.). The final geometry of the crucible is shown in Figure 7.

FIGURE 7. Final Geometry of MgO Inserts

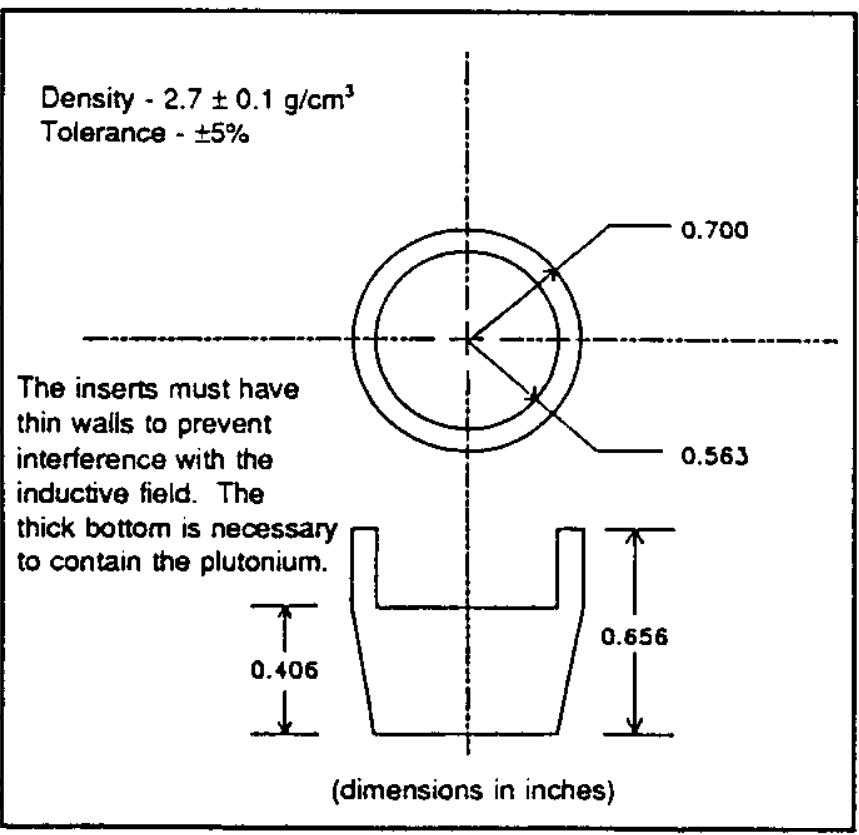

Three different ceramic microstructures werc also examined. Dense, low-porosity $\left(3.3 \mathrm{~g} / \mathrm{cm}^{3}\right) \mathrm{MgO}$ inserts broke when subjected to thermal shock associated with the carbon analysis and failed to contain the molten plutonium. Lower-density $\left(2.7 \mathrm{~g} / \mathrm{cm}^{3}\right)$ inserts fired to a final tempcrature of $1400^{\circ} \mathrm{C}$ withstood the thermal shock but produced an excessively high (>150 ppm) carbon blank. The carbon blank refers to the amount of carbon relcased from the insert when loaded with the copper accelerator only. Low-density inserts fired to a higher tempcrature $\left(1595^{\circ} \mathrm{C}\right)$ withstood the thermal shock and produced carbon blanks less than $10 \mathrm{ppm}$. The final fabrication technique developed for these inserts is described in Appendix A.

After developing a geometry and microstructure with a low carbon blank that adequately contained the plutonium, an off-site vendor* fabricated the large quantities of inserts to complete development. Physical testing was conducted to determine whether the vendor-supplied $\mathrm{MgO}$ inserts would consistently contain the plutonium sample during analysis, resist the associated themal shock, and readily separate from the LECO crucible holder after analysis. A total of two hundred insers were used for the physical testing.

All of the MgO inserts performed satisfactorily against thermal shock and all contained most of the plutonium metal. The copper accelerator had a tendency to penetrate into the inser and a small amount of copper oxide was left on the inner surface of the LECO holder. Immediately after analysis, the inserts were wedged in the LECO holder because of differential thermal cxpansion. However, after cooling about 30 seconds, the inserts cleanly separated from the LECO holder. Presence of copper oxide on the inner surface of the holder did not cause sticking even after the holder had been reused 25 times.

To cnsure that most of the plutonium remained in the inser, three LECO crucibles (used 25 times cach as a holder) were analyzed for plutonium content. Plutonium amounting to $0.028 \mathrm{~g}$ was

"Orark Technical Ccramics, Inc. 
found in the three LECO holders. During analyses of $32.5 \mathrm{~g}$ of plutonium (75 analyses $\times 0.5 \mathrm{~g}$ plutonium/analysis), more than $99.9 \%$ of the plutonium remained in the insert.

\section{ANALYTICAL RESULTS}

To be effective, it is important that inserts do not affect accuracy of the LECO carbon analysis. To determine whether the inserts have detrimental effect on reliability of the carbon analysis, several samples of plutonium and plutonium oxide reference material were analyzed with and without the inserts.

The first tests were conducted with inserts fabricated at Rocky Flats. The results (Table 1) indicate that the inserts had no significant effect on the process and their presence could be essentially ignored. However, when tests were repeated with inserts from an off-site vendor, the samples with inserts had carbon analyses higher than those without inserts. The problem was traced to a high carbon blank in the insert. The inserts from the off-site vendor were made using the procedure

TABLE 1. Carbon Analysis of Newly Made Inserts

\begin{tabular}{ll}
\multicolumn{2}{l}{ Pluconium Metal } \\
LECO & MgO Insert \\
$=6$ & $\mathrm{~N}=8$ \\
$\mathrm{x}=216 \mathrm{ppm}$ carton & $x=220 \mathrm{ppm}$ carbon \\
$s=27.2 \mathrm{ppm}$ carbon & $s=14.3 \mathrm{ppm}$ carbon \\
$\%$ RSD $=12.6$ & $\% R S D=6.5$
\end{tabular}

Plutonium Oxide

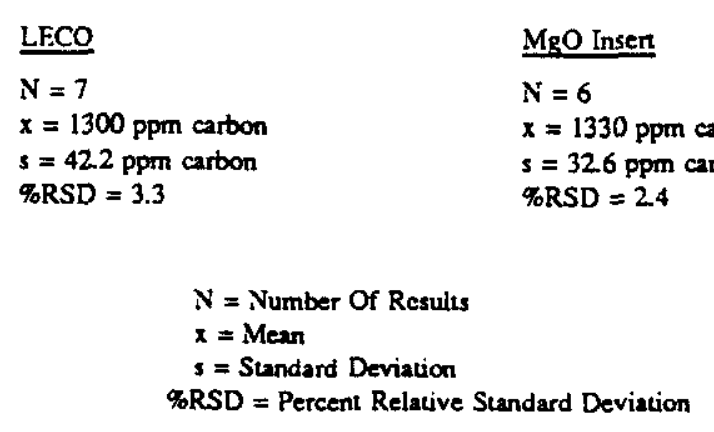

established at Rocky Flats, the only difference being the age of the inserts at the time of use. The Rocky Flats inserts were only about one day old when used, while those received from offsite were more than two weeks old. Refiring the vendorsupplied inserts to $1575{ }^{\circ} \mathrm{C}$ for 4 hours reduced the blank to $0-5 \mathrm{ppm}$ carbon, indicating they slowly adsorbed carbon dioxide from the air. ${ }^{2}$

To confirm this theory, 25 inserts were refired to $1595^{\circ} \mathrm{C}$ for 4 hours, and blanks were determined on sets of five inserts at periods ranging from 0 to 30 days. Figure 8 shows that the carbon blank was very low for the first 24 hours; but after four to six days, they increased to more than $20 \mathrm{ppm}$. The data point at 30 days indicates the inserts continue to adsorb carbon dioxide but at a decreasing rate.

Packaging was initially considered as a means of preventing the adsorption of $\mathrm{CO}_{2}$, but simple packaging techniques such as Ziplock ${ }^{\mathrm{TM}}$ bags or heat-sealed bags were not effective in preventing the adsorption. More elaborate packaging would have been impractical for the large number of inserts required for production use. Therefore, different refiring treatments were investigated to determine whether the carbon blank could be reduced to an acceptable level.

Refiring the inserts to $1575^{\circ} \mathrm{C}$ for four hours reduced the inser blanks below 5 ppm. However, refiring the inserts at $1000{ }^{\circ} \mathrm{C}$ for 30 minutes consistently reduced the blanks to $10-15 \mathrm{ppm}$ and

FIGURE 8. Carbon Dioxide Adsorption

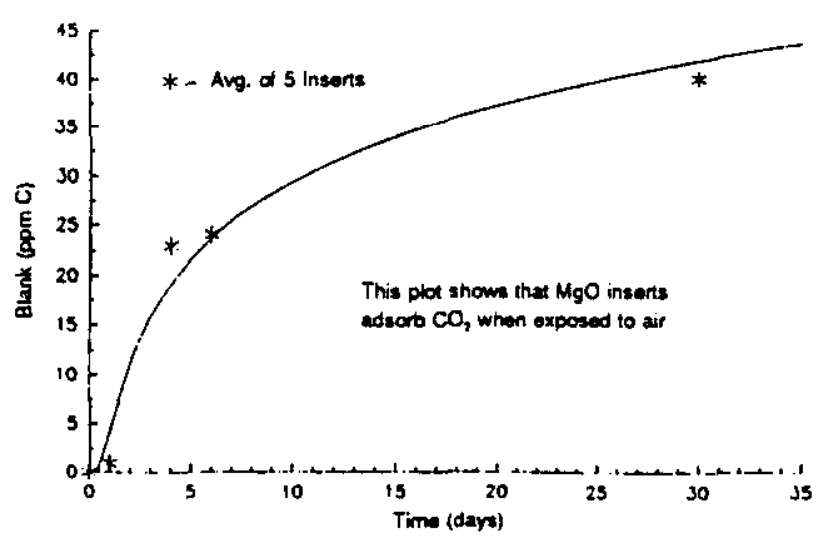


TABLE 2. Carbon Analysis of Older Inserts, Refired at $1000^{\circ} \mathrm{C}$ for 30 Minutes

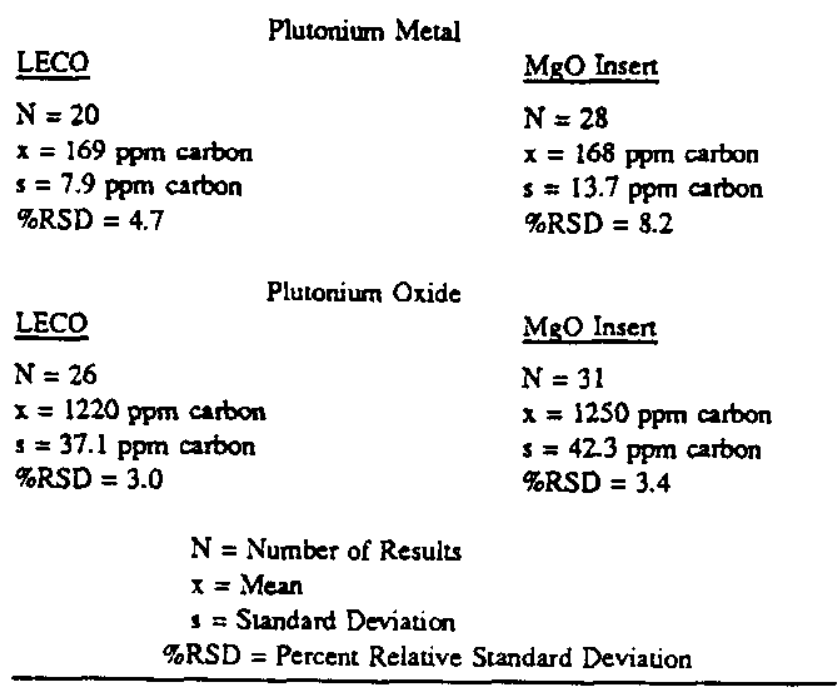

could be accomplished with existing equipment available in the same general area as the LECO carbon analyzer. The $1000^{\circ} \mathrm{C}$ refiring procedure was, therefore, more practical from a production standpoint. The consistent blank of 10-15 ppm could readily be compensated for by using the autoblanking feature of the LECO carbon analyzer, which automatically subtracts the blank value from the analysis to produce correct carbon values.

Several samples of plutonium and plutonium oxide reference material were run with and without the inserts to determine whether the $1000^{\circ} \mathrm{C}$ refire was a practical and repeatable solution to the problem. Inserts several months old were refired at $1000^{\circ} \mathrm{C}$ for 30 minutes and used for this second set of tests. Table 2 shows that the refired inserts did not significantly affect the carbon numbers obtained with the LECO carbon analyzer. Therefore, if the insers are refired and the autoblanking feature of the LECO analyzer is utilized, the inserts can be used in production without significantly affecting the analytical results.

\section{RECOVERY TESTS}

The residue that must be recovered after using the $\mathrm{MgO}$ inserts in the carton analyzer consists mainly of $\mathrm{MgO}$, copper oxide ( $\mathrm{CuO}$ ), and a high fired form of plutonium oxide. Both $\mathrm{MgO}$ and $\mathrm{CuO}$ readily dissolved in nitric acid. Plutonium oxide can be dissolved in nitric acid under reflux conditions if a small quantity of fluoride is present to act as a catalyst.

Rocky Flats has a nitric acid/calcium fluoride dissolution line, which is used to recover the large quantity of $\mathrm{MgO}$ waste generated in the fluoride reduction process. To determine whether this line could be used for recovery, residue from 370 inserts $(2454 \mathrm{~g})$ containing $61.3 \mathrm{~g}$ of plutonium was processed through this line. The residue was crushed to approximately 60 mesh and run through the dissolution line at a rate of $1 \mathrm{~kg} / \mathrm{hr}$. Ten liters of $12 \mathrm{~N}$ nitric acid were used per kilogram of residue, and calcium fluoride was added $(60 \mathrm{~g} / \mathrm{kg})$ to provide the fluoride catalyst. The process was conducted at temperatures ranging from 95 to $103^{\circ} \mathrm{C}$. These are normal operating parameters for recovering residues that do not contain a fluoride source.

After processing, the dissolution heel (residue that failed to dissolve) was collected, dried, and assayed (Table 3).

TABLE 3. Assay of Dissolution Heel

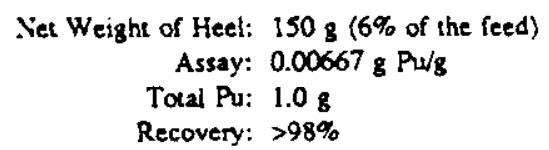

The $98 \%$ recovery showed that the nitric acid/calcium fluoride dissolution process did an excellent job recovering the plutonium from the $\mathrm{MgO}$ insert residue. However, the overall size of the heel was larger than expected and a sample was analyzed. The major portion was calcium fluoride with lesser amounts of $\mathrm{MgO}$ and other unidentified trace elements. Therefore, most of this heel was probably $\mathrm{CaF}_{2}$ carried over from previous dissolution runs.

\section{COST ANALYSIS}

Several Rocky Flats investigators have proposed different methods for recovering the LECO 
crucible residues.' Although several methods had high plutonium recoveries, the only process available for recovering production quantities of LECO residues in the near future is the nitric acid/calcium fluoride dissolution process. Therefore, the cost analysis compares the expense of recovering plutonium from LECO crucibles using the nitric acid/calcium fluoride dissolution process to the cost of recovering plutonium from the $\mathrm{MgO}$ inserts using the same process.

\section{ASSUMPTIONS FOR COST ANALYSIS CALCULATIONS}

The following assumptions were used to calculate the cost estimate of $\mathrm{MgO}$ insert recovery reported in Table 4.

1. The dissolution efficiency for the $\mathrm{MgO}$ inserts is $98 \%$, based on experimental data obtained from the dissolution tests.

2. The dissolution efficiency for the bulk LECO residue is $30-50 \%$ for the first pass and 15 $30 \%$ for subsequent passes. Recovering $90 \%$ of the plutonium will require 4-7 passes. These numbers are based on a proposed flow scheme for processing LECO crucibles with the nitric acid/calcium flouride dissolution

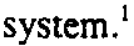

3. Processing $1 \mathrm{~kg}$ of bulk material through the nitric acid/calcium fluoride dissolution system costs $\$ 222$ and generates about $21.5 \mathrm{l}$ of process solutions.

4. The cost for processing one liter of solution through the Rocky Flats waste processing is $\$ 1.11$.

5. The weight of an insert is $6.5 \mathrm{~g}$ and the weight of a LECO crucible is $18.5 \mathrm{~g}$.

6. Each carbon analysis uses $0.5 \mathrm{~g}$ of plutonium and $1.0 \mathrm{~g}$ of copper accelerator.

7. Fifteen thousand carton analyses are conducted each year.
8. Crucibles are crushed to a powder $<35$ mesh.

9. Both wastes can be dissolved without significant changes in the normal operating procedure and neither waste causes increased degradation of the components in the dissolution line.

TABLE 4. Estimated Recovery Cost Savings for MgO Inserts vs. LECO Residues

MGO Inserts
(Single Pass)

\begin{tabular}{|c|c|c|c|}
\hline \multicolumn{4}{|l|}{$\begin{array}{l}\text { Cost of Processing } \\
\text { Bulk Material }\end{array}$} \\
\hline $120 \mathrm{~K}_{8}$ & $\$ 26,600$ & & \\
\hline $675 \mathrm{~K}_{8}$ & & $\$ 149,900$ & \\
\hline $1260 \mathrm{Kg}$ & & & $\$ 279,700$ \\
\hline \multicolumn{4}{|l|}{$\begin{array}{l}\text { Cost of } \\
\text { Inserts/Crucibles }\end{array}$} \\
\hline $\begin{array}{l}\text { Inserts } \\
\text { Interst }\end{array}$ & $\$ 30,000$ & & \\
\hline LECO Cnucibles & & $\$ 1600$ & $\$ 1600$ \\
\hline \multicolumn{4}{|l|}{ Cost of Processing } \\
\hline $\begin{array}{l}\text { Solutions Generated } \\
\text { in Recovery Process }\end{array}$ & & & \\
\hline 2600 Liten & $\$ 2900$ & & \\
\hline 14,500 Liters & & $\$ 16,100$ & \\
\hline 27,000 Liters & & & $\$ 30,000$ \\
\hline Total Cost & $\$ 59,500$ & $\$ 167,600$ & $\$ 311,300$ \\
\hline Savings & ...- & 5108,100 & $\$ 251,800$ \\
\hline
\end{tabular}

The cost analysis demonstrates that the yearly savings associated with using the inserts is between $\$ 108,000$ and $\$ 251,000$, depending on the number of passes required for the LECO residue. If all assumptions are accurate, using the $\mathrm{MgO}$ inserts will produce significant cost savings. However, the inserts are even more appealing when the validity of Assumptions 8 and 9 are examined.

The use of the $\mathrm{MgO}$ inserts will generate residue similar to the sand/slag/crucible residues generated in the plutonium fluoride reduction process. Plutonium from thousands of kilograms of this material have been recovered using the nitric acid/calcium fluoride dissolution process. The 
inserts are relatively easy to reduce to $<35$ mesh and readily dissolve in the nitric acid/calcium fluoride line using normal operating procedures.

On the other hand, the LECO crucible residue will require significant changes in the dissolution process.' The LECO crucibies are composed of $\mathrm{SiO}_{2}, \mathrm{Cr}_{2} \mathrm{O}_{3}$, and $\mathrm{Al}_{2} \mathrm{O}_{3}$, all of which are much harder than $\mathrm{MgO}^{3}$ This makes the crucibles very difficult to grind and new production grinding equipment would have to be purchased to reduce the LECO residue to $<35$ mesh. The LECO residue may also cause other problems. For example, aluminum nitrate is often added to the dissolution process to complex the fluoride and thereby minimize corrosion of the materials in the dissolution line. However, this practice would have to be stopped if the LECO residue was processed because a gelatinous precipitate is likely to form, causing plugging problems in subsequent recovery steps. Significant silica buildup in both the dissolution and off-gas equipment would also create problems.

\section{CONCLUSIONS}

1. The use of $\mathrm{MgO}$ inserts in the LECO Carbon Analyzer will prevent the generation of LECO crucible residue.

2. Yearly cost of recovering the plutonium from the inserts is estimated to be $\$ 108,000$ $\$ 251,800$ less than the cost of recovering plutonium from standard LECO residues.

3. The one-pass plutonium recovery efficiency for $\mathrm{MgO}$ inserts in the nitric acid/calcium fluoride dissolution line exceeds $98 \%$ when standard operating parameters are used.
4. The inserts must have thin walls and a thick bottom to maintain the proper buming characteristics of the copper acclerater while consistently containing the plutonium during analysis.

5. The inserts must have a low-density, high-fired microstucture to prevent themal shock from breaking the insert during LECO Carbon Analysis.

6. More than $99.9 \%$ of the plutonium used in the LECO carbon analysis will remain in the insert after analysis.

7. The insert's tendency to adsorb carbon dioxide can readily be handled by refining the inserts at $1000^{\circ} \mathrm{C}$ for 30 minutes prior to use.

8. Insert refiring and analyzer calibration allow the inserts to be used in production without significantly effecting the analytical results.

\section{REFERENCES}

1. J. F. Kirchner, LECO Crucible Recovery - $A$ Review of Processing Oprions, RFP-4388, Rockwell International, Rocky Flats Plant, Golden, CO.

2. W. D. Kingery, H. K. Bowen, and D. R. Uhimann, Introduction to Ceramics, John Wiley \& Sons, 1976

3. J. F. Lynch, Editor, Engineering Property Data On Selected Ceramics Volume III, Single Oxides, Battelle Laboratories Report MCICHB-07, July 81, Batelle Columbus Laboratories, Columbus, $\mathrm{OH}$. 
RFP-4339 


\section{APPENDIX A. \\ FABRICATION STEPS FOR MgO INSERTS}

1. Five hundred grams of 40 -mesh $\mathrm{MgO}$ were mixed with $25 \mathrm{~g}$ of Carbowax@ $20 \mathrm{M}$ and $125 \mathrm{~g}$ of Ethanol and ball milled for two hours.

Ball milling the 40-mesh powder for two hours resulted in a particle-size distribution coarse enough for the inserts to be fired to high temperatures without significant densification. The Carbowax was added to act as both a binder and a die lubricant. Ethanol was used to prevent hydration problems associated with using water as a suspending medium.

2. The milled powder was pan dried and ground with a morar and pestle until it could pass through a 60-mesh screen.

The alcohol was easily driven off and left an agglomerated powder that was readily crushed.

Powder that passed a 60-mesh screen had good flow characteristics and consistently filled the die.

3. Ten grams of powder were loaded into a $3 / 4$-in. die and pressed at 18,000 psi.

The dry pressing process yieided blanks with consistent dimensions and good green strength.

4. The blanks were fired at $1500^{\circ} \mathrm{C}$ for three hours.

This first, lower temperature firing was to bum off the Carbowax binder and sinter the blank for sufficient strength to hold together during the subsequent machining operation.

5. The fired blanks were wet machined to final shape using diamond grinding tools.

The procedure of pressing a blank, firing it, and machining to final shape was necessary because of the required geometry of the part and the limited number of inserts to be fabricated. Once fully implemented, the cost of tooling for pressing parts to final shape would be justified.

6. The machined blanks were refired to $1575^{\circ} \mathrm{C}$ for three hours.

This final high temperature fining was necessary to further sinter the insert and reduce the surface area available for adsorption of $\mathrm{CO}_{2}$. 
RFP-4339

U.S. gOVEANMENT PRINTING OFFICE : 1991 - 574-196

12 